
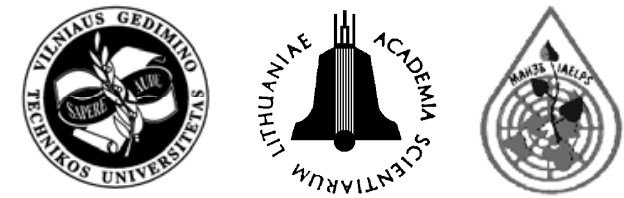

\title{
COMPARISON OF THREE TREE-RING SAMPLING METHODS FOR TRACE METAL ANALYSIS
}

\author{
Edita Baltrènaité ${ }^{1}$, Donatas Butkus ${ }^{2}$, Colin A. Booth ${ }^{3}$ \\ ${ }^{1,2}$ Dept of Environmental Protection, Vilnius Gediminas Technical University, \\ Sauletekio al. 11, LT-10223 Vilnius, Lithuania \\ ${ }^{3}$ School of Engineering and the Built Environment, The University of Wolverhampton, Wulfruna Street, \\ Wolverhampton WV1 1LY, United Kingdom \\ E-mails: ${ }^{1}$ Edita.Baltrenaite@vgtu.lt; ${ }^{2}$ Donatas.Butkus@vgtu.lt; ${ }^{3}$ C.Booth@wlv.ac.uk \\ Submitted 3 Sept. 2006; accepted 1 Feb. 2010
}

\begin{abstract}
Tree-ring growth analysis can provide information about tree development for forest inventory, environmental assessment, atmospheric and soil monitoring. Metal concentrations in wood increment correlate with metal concentrations in the environment and can indicate local environmental contamination sources. One of the most important steps of tree analysis is tree-ring sampling. To determine trace metal (TM) concentrations precisely in a separate ring, the possibility of random errors during wood sampling must be eliminated. This guides to choose a precise tree-ring sampling method. This paper examines three tree-ring sampling tools (common chisels, arched chisels and a plane) and compares TM concentrations (Mn, Zn, Ni, Cr, Cu, Pb,) in wood samples collected by each of the methods employed. Average values of metals in tree rings sampled with common chisels, arched chisels and plane were $17.0 \pm 0.16 \mathrm{mg} / \mathrm{kg}$ for $\mathrm{Mn}, 4.7 \pm 0.21 \mathrm{mg} / \mathrm{kg}$ for $\mathrm{Zn}$, $0.49 \pm 0.20 \mathrm{mg} / \mathrm{kg}$ for $\mathrm{Pb}, 0.29 \pm 0.02 \mathrm{mg} / \mathrm{kg}$ for $\mathrm{Cu}, 0.21 \pm 0.02 \mathrm{mg} / \mathrm{kg}$ for $\mathrm{Ni}$ and $0.12 \pm 0.01 \mathrm{mg} / \mathrm{kg}$ for $\mathrm{Cr}$ and were in the range of typical concentrations in investigated region as well as for Pinus sylvestris L. The average values were calculated for the three methods used. Statistical analysis (Anderson-Darlin test, Kruskal-Wallis tests, median and percentage coefficient of variation) revealed no significant differences between metal concentrations determined in tree rings which were sampled using common chisels, arched chisels and planing. Various techniques - common chisels, arched chisels and plane - can be successfully used for tree-ring sampling, however, an increment borer provides possibility of sampling a nonfelled tree.
\end{abstract}

Keywords: trace metals, chisel, wood samples, tree ring, plane.

\section{Introduction}

Tree-ring growth analysis can provide information about tree development for forest inventory, environmental assessment, atmospheric and soil monitoring. Tree-ring studies can show climate change patterns, e.g. those related with droughts, humid periods and accidents such as fires (Alexander 1999; McLaughlin 2002).

Decades of anthropogenic activities have led to higher amounts of trace metals (TMs) reaching forests (and solitary trees) in the form of dry and wet deposition. Synergetic effect of TMs with other industrial contaminants inhibits tree vitality and depresses tree nutritional functions (Ozolinius, Sujetovienė 2002, Rademacher 2003; Stravinskiene, Šimatonytė 2008; Stravinskienè, ErlickytėMarčiulionienè 2009).

Tree root ability to take up TMs from the soil and atmosphere enables trees to be used as biological indicators, capable to accumulate TMs in tree rings and, thus, hold a record of environmental contamination data (DeWalle et al. 1995; Butkus et al. 2002, 2008; White, Tard 2002; Ozolinčius 2004). High correlation between concentrations of TMs in the soil and xylem rings has been reported (Larison, Helmisaari 1998). For example, increased lead $(\mathrm{Pb})$ concentration in the annual growth rings of trees has been shown to relate with atmospheric $\mathrm{Pb}$ deposition of automobile exhaust emissions (Rolfe 1974; Kardell, Larsson 1978; Guyette et al. 1991; Latimer et al. 1996). Similarly, levels of manganese (Mn) in Scots pine stem are high in old annual rings and decrease towards the bark (Butkus et al. 2002; Baltrènaitè, Butkus 2004). Nickel (Ni) is found in the trees at industrially polluted soils, areas affected by transport (Kirchner et al. 2008), and soils amended with sewage sludge (Katinas et al. 2002; Montse, Joan 2006). Copper (Cu) and zinc (Zn) are among elements commonly emitted from smelters and they are observed to be antagonistic. Zn concentration has been found to increase towards the bark in the studied trees (Larison, Helmisaari 1998).

Metal concentrations in wood increment correlate with metal concentrations in the environment and can indicate local environmental contamination sources. For instance, results from a previous investigation showed intense transfer of $\mathrm{Zn}$ and $\mathrm{Cu}$ from the soil to pine trees in two military training areas in Lithuania (Baltrènaitè, Butkus 2006). The explanation given was that $\mathrm{Zn}$ and $\mathrm{Cu}$ were known as constituents of military activity; Zn was a component of bullets and $\mathrm{Cu}$ - a component of military transport emissions (Baltrènaitè, Butkus 2004; Baltrènas et al. 2005). Pines grown in three military training areas had 
about twice lower concentration of $\mathrm{Cr}, \mathrm{Mn}, \mathrm{Pb}$ and $\mathrm{Ni}$ in tree rings during the period 1989-1996, compared with 1978-1988 and 1997-2001, the periods known as the Lithuanian independence regeneration with decline of Soviet military activities and, therefore, less military transport emissions (Baltrènaitè, Butkus 2006).

Variation in metal concentrations may indicate tree disease. For instance, it was reported that in Scots pine tree rings of 1959-1960, infected with root rot (Heterobasidion annosum (Fr.) Bref.), concentrations of $\mathrm{Ni}$ and chromium (Cr) were 4 and 7 times higher, respectively, than mean TM concentrations in non-affected wood. Possible defensive functions of TMs in a tree against biotic stress have been hypothesized (Baltrènaitè, Butkus 2006; Poschenrieder et al. 2006).

One of the most important aspects of tree growth analysis is tree-ring sampling. To determine TMs concentration precisely in a separate ring, the possibility of random errors during wood sampling must be eliminated. This guides to choose a precise tree-ring sampling method.

Wood sampling procedures to determine wood physical properties, tree age, diseases are well documented (Antonova et al. 1995; Camarero et al. 1998; Horacek et al. 1999; Nelson et al. 2000; Schmitt et al. 2003; Stravinskienè 2005; Rossi et al. 2006). However, tree-ring sampling for TM analysis is still scarce. Nelson et al. (2000) reported three different wood sampling methods in paper and pulp production: (a) cutting cylinders from a stem and graining; (b) crushing large wood slivers, and (c) using wood chips. Correlation was calculated to be higher than 0.80 between pulp concentration and wood amount after all methods used (Nelson et al. 2000).

To examine wood structure non-specific tools (surgical bone needle, trap system needle, trephor) to sample micro-cores were reported (Rossi et al. 2006). Extracted micro-cores are 15-20 mm in length and the inner size of cutting tube is about $1.2-2.0 \mathrm{~mm}$ in diameter. The mass of such a micro-core varies from 25 to $50 \mathrm{mg}$ and is sufficient for microscopic analysis but not for determination of TMs concentration and, especially, when separate tree rings are needed. Hence, the sampling method has to be cheap, easy to administer and provide sufficient amount of samples for further analysis.

This paper examines three tree-ring sampling tools (common chisels, arched chisels and a plane) and compares TMs concentrations ( $\mathrm{Mn}, \mathrm{Zn}, \mathrm{Ni}, \mathrm{Cr}, \mathrm{Cu}, \mathrm{Pb}$,) in wood samples collected by each of the approaches employed (Godbold and Hüttermann 1985; Breckle 1991; Nies 1999).

\section{Methods}

\subsection{Sampling site}

The investigated single pine tree (30 m high, $0.4 \mathrm{~m}$ thick, 55 year-old) was located in southern Lithuania, $10 \mathrm{~km}$ from the town of Alytus (Fig. 1a, b; site coordinates: E024 $02^{\prime}$ '56.9” N54 18 '33.7'), which is widely known to have had an intense industry when Lithuania was a part of Soviet Union (1940-1991). According to geochemical investigations carried out in 1998-1999, the soils are known to contain dangerously high metals contamination derived from nearby refrigerator and textile factories (Kadūnas et al. 1999). The anthropogenic load to topsoil consists mainly of metals such as $\mathrm{Zn}, \mathrm{Pb}, \mathrm{Cu}, \mathrm{Cd}, \mathrm{Ni}, \mathrm{Cr}$, Hg, Ag, Sn and Mo (Kadūnas et al. 1999).

a)

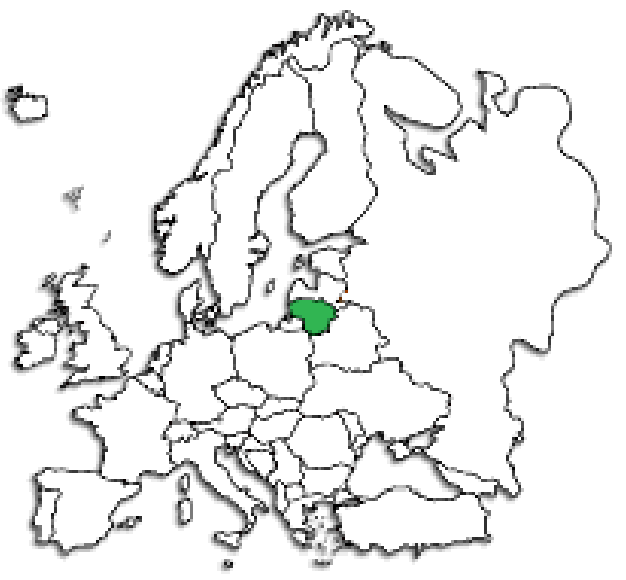

b)

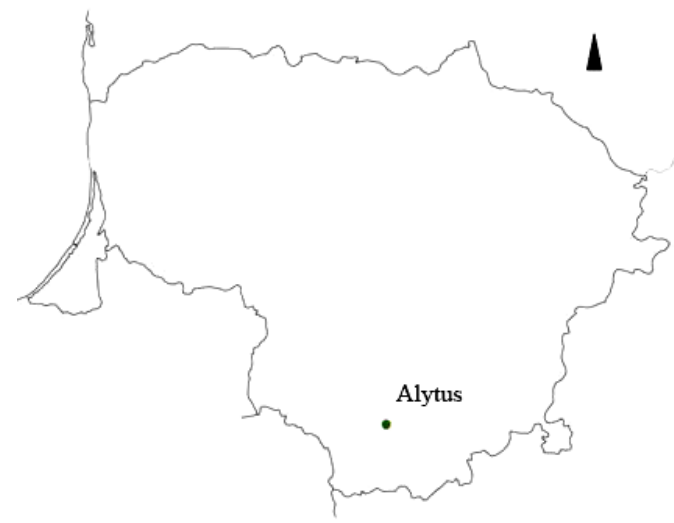

Fig. 1. Location of Lithuania in Europe (a); location of sampled tree (b)

Soil in the investigated area is sandy loam with a mean $\mathrm{pH}$ of 5.5. Landscape is hilly with an inclination of 3-5 degrees. Forest litter thickness varies from 4 to $5 \mathrm{~cm}$; mean annual temperature is around $6.0^{\circ} \mathrm{C}$. South-western wind with speed of $4.2 \mathrm{~m} / \mathrm{s}$ prevails in the region. Mean annual precipitation is $619 \mathrm{~mm}$. Pines prevail in Alytus region and cover $70-80 \%$ of the investigated forest area (Butkus, Beinaravičius 2005).

A single pine tree was randomly selected (Wilson 2005) from a group of pines growing in the vicinity of the exposed industrial zone. Permission was gained and granted to fell but was restricted to one tree. This was sampled at the beginning of vegetation period - late April (Hill 2002; Trapp 2007). 


\subsection{Wood sampling methods}

The investigated pine tree was chain-sawn and three sections (each $5 \mathrm{~cm}$ wide) were cut at three different heights: $1 \mathrm{~m}$ above the ground, in the middle of the tree-trunk and at $3 / 4$ of the trunk height (Fig. 2). The bark layer was removed and sections were air-dried in the laboratory. The surface of each section was polished to reveal the tree-ring patterns and a marker was used to highlight the boundaries of sequent annual rings.

Tree-ring sampling with common chisels (Fig. 3b). Using common chisels wood rolls were split into slivers containing one ring in the tangental direction (Taylor et al. 2003; Butkus et al. 2007).

Tree-ring sampling with arched chisels (Figs. 3a and 4). The method is similar to that mentioned above. The difference is in chisels that are arched to repeat treering curvatures (Fig. 5).

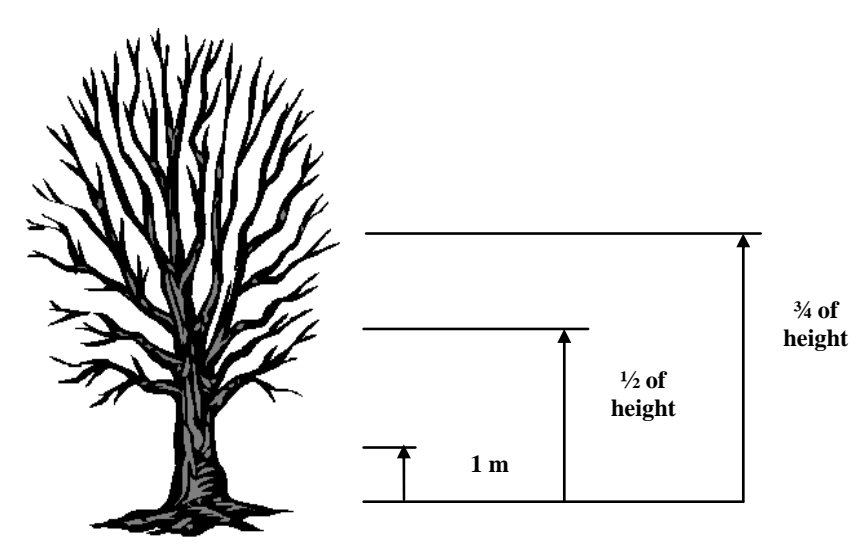

Fig. 2. Heights for cross-section sampling

a)

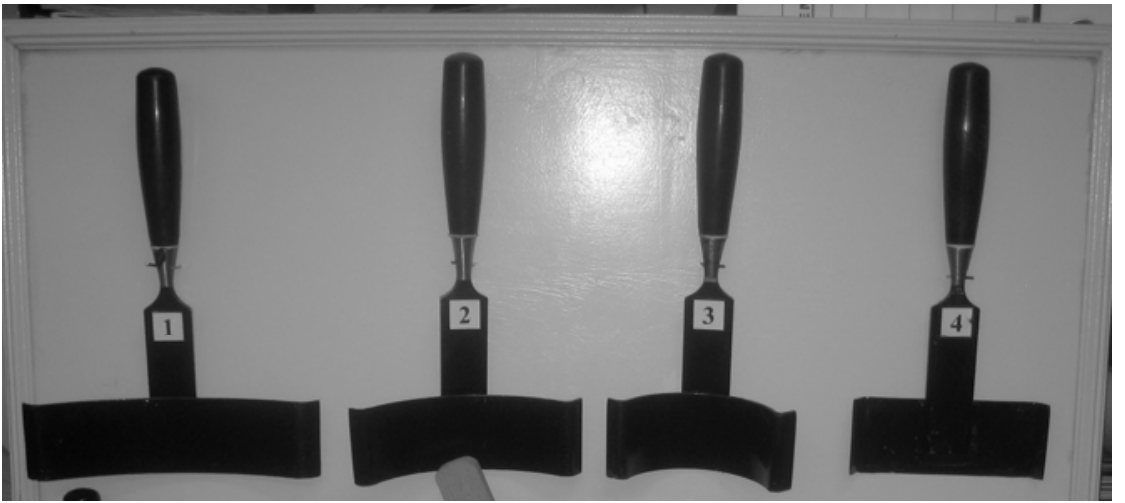

b)

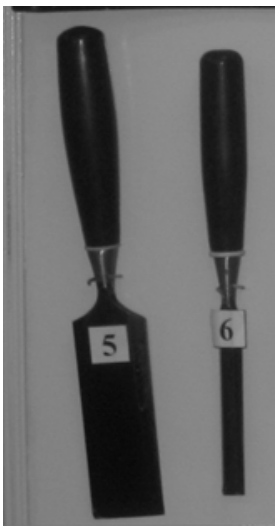

c)

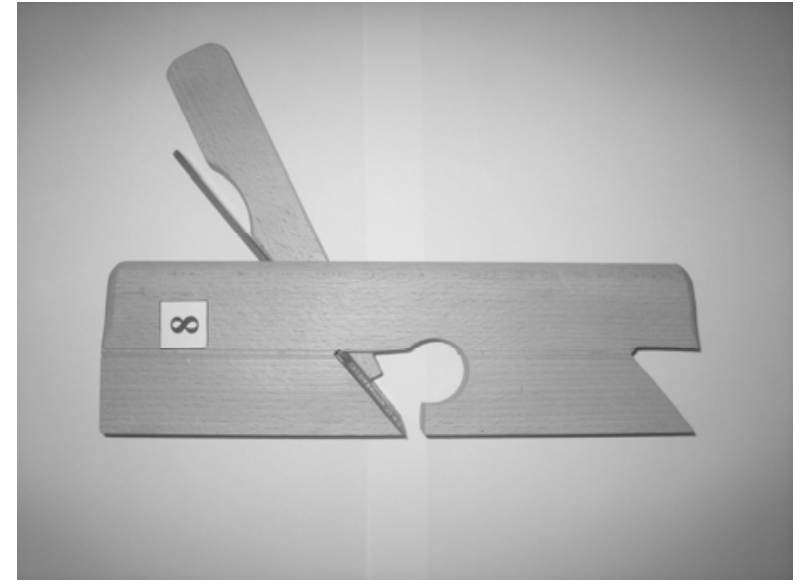

Fig. 3. Produced tree-ring sampling equipment: a) No 1, 2, 3, 4 - arched chisels; b) No 5, 6 - common chisels; c) No 8 - plane 


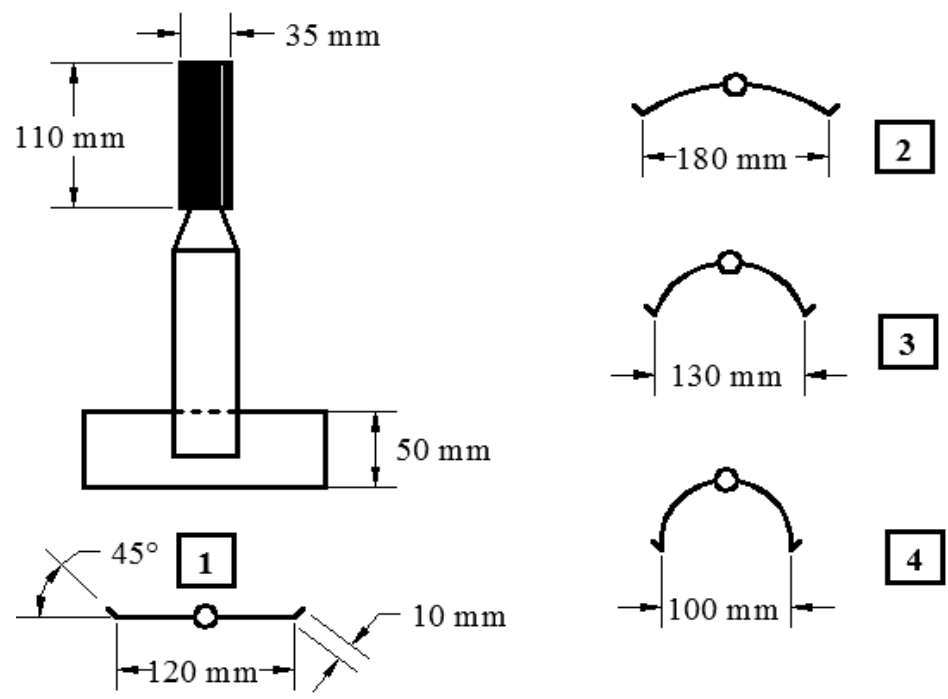

Fig. 4. Tree-ring sampling tools: No 1 - common chisel, No 2, 3, 4- differently arched chisels (Beinaravičius 2005)

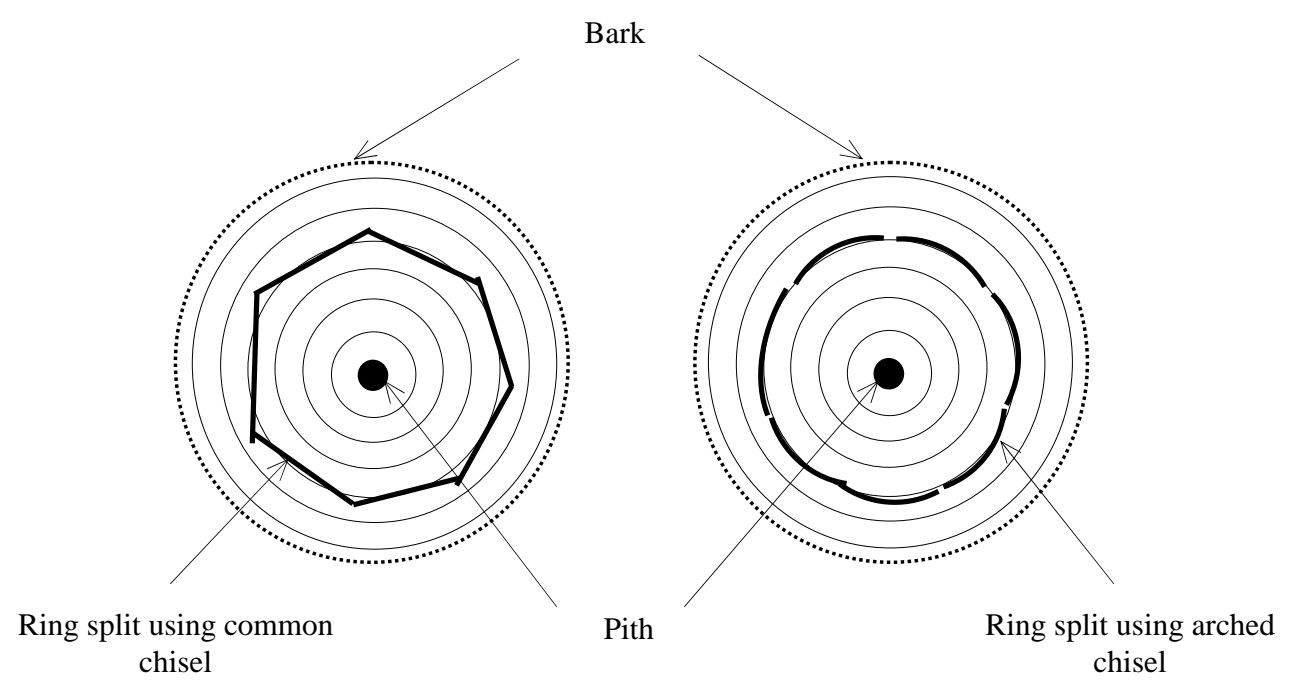

Fig. 5. Schematic view of ring splitting using two tools: common and arched chisels

Arched chisels are developed to separate tree rings of wooden plants of 10-80 years. A flat one is used to remove the bark and separate rings from rolls larger than $500 \mathrm{~mm}$ in diameter. To reduce risk of higher random errors the height of the roll cannot exceed $5 \mathrm{~cm}$. Chisel blades were extended by welding plates on their surface produced from particularly hard steel which is resistant to long-term use and deformation. The leaning angle of a blade is $25^{\circ}$ and the height of a sharpened blade is $10 \mathrm{~mm}$. A number of differently arched chisels were produced to fit ring curvature and reduce the risk of sampling error during the ring separation procedure. Chisel blades were extended with $10 \mathrm{~mm}$ of length-limiting extensions, perpendicular to a blade, which do not allow a ring to deviate and makes ring samples of a more accurate shape. Later rings should be sampled with chisels of a larger diameter and less arched, and rings close to the pith should be separated using chisels of a smaller diameter and higher arched (Fig. 3).

Tree-ring sampling with a plane. Separate ring samples were formed out of chips after planing away separate rings. Mass of one-specimen samples using common and arched chisels and a plane was in the range of 200-300 g (Fig. 3c).

Tree-sampling tools were produced at the Department of Environmental Protection (Vilnius Gediminas Technical University, Lithuania).

\section{Preparation of wood samples}

After dissection (by the three techniques) the wooden samples were ground with a Retsch grinding machine RM 200 to 3-5 mm particles and prepared for TM analysis by digestion. Wood samples of $0.5 \mathrm{~g}$ each were taken and mixed with $8 \mathrm{ml}$ of $\mathrm{HNO}_{3}(65 \%)$ and $2 \mathrm{ml}$ of $\mathrm{H}_{2} \mathrm{O}_{2}$ 
(30\%). Then they were poured into specific vessels and put into a microwave digester Milestone ETHOS to be digested for $31 \mathrm{~min}$. The solutions were poured into $50 \mathrm{ml}$ flasks and diluted with deionized water to the mark of $50 \mathrm{ml}$. A parallel procedure was used for the five blanks (Soon, Abboud 1993).

\subsection{Analysis of trace metal concentrations}

A total of TMs was determined by flame atomic absorption spectrophotometer (FAAS). When they were below detection limits, graphite furnace atomic absorption spectrophotometer (GFAAS) was employed. Detection limits of $\mathrm{Mn}, \mathrm{Ni}, \mathrm{Zn}, \mathrm{Pb}, \mathrm{Cu}$ and $\mathrm{Cr}$ were $2.0 ; 90 ; 0.5 ; 10 ; 1.0$ and $3.0(\mu \mathrm{g} / \mathrm{l})$ by FAAS and $0.01 ; 0.1 ; 0.001 ; 0.05 ; 0.02$ and $0.01(\mu \mathrm{g} / \mathrm{l})$ for GFAAS.

\subsection{Data analysis}

Anderson-Darling tests were carried out to observe the normality of the elemental data for each tree-sampling technique. On the basis of that, nonparametric KruskalWallis test was employed to investigate differential data of the methods. Median data and percentage coefficient of variation $(\mathrm{CoV})$ were also determined.

\section{Results and discussion}

The results of TMs in wood showed no elevated values (Fig. 6) and were in the range of concentrations found in pine trees in the same region: $\mathrm{Ni}-0.1-3.50 \mathrm{mg} / \mathrm{kg}$; $\mathrm{Cr}-0.1-1.50 \mathrm{mg} / \mathrm{kg} ; \mathrm{Cu}-0.25-3.00 \mathrm{mg} / \mathrm{kg} ; \mathrm{Mn}-10$ 160 mg/kg; Zn - 2-75 mg/kg, Pb - 0.05-2.80 mg/kg (Butkus, Baltrènaitè 2007). Cu and Cr concentrations were in the range of values found in similar growing conditions abroad: $\mathrm{Cr}$ - 0.12-0.46 mg/kg; Cu - 0.15-1.02 mg/kg (Padilla, Anderson 2002). The highest concentrations in pinewood were typical of $\mathrm{Mn}$ and $\mathrm{Zn}(1.695 \pm 0.161 \mathrm{mg} / \mathrm{kg}$ and $0.471 \pm 0.206 \mathrm{mg} / \mathrm{kg}$, respectively) followed by $\mathrm{Pb}$ $(0.487 \pm 0.202 \mathrm{mg} / \mathrm{kg})$ and $\mathrm{Cu}(0.290 \pm 0.021 \mathrm{mg} / \mathrm{kg})$. The lowest concentrations were found for $\mathrm{Ni}(0.210 \pm$ $0.023 \mathrm{mg} / \mathrm{kg})$ and $\mathrm{Cr}(0.117 \pm 0.010 \mathrm{mg} / \mathrm{kg})$. Mn and $\mathrm{Zn}$ accumulation in tree xylem is considered to be associated with tree growth (Baes, McLaughlin 1984), hence, high amounts of $\mathrm{Mn}$ and $\mathrm{Zn}$ compared with the rest of the investigated metals indicated healthy tree growth conditions. The majority of $\mathrm{Pb}$ in tree wood comes from atmospheric pollution either directly through aerial interception or indirectly through the uptake of a highly Pb-contaminated soil (Bindled et al. 2004) which was not the case on the investigated site. Thus the source of $\mathrm{Pb}$ was likely the aerial uptake. $\mathrm{Cu}$ and Ni reach wood xylem by root uptake from acidic soils or the bark. $\mathrm{Pb}$, if entered through the bark, is transported radially to a lesser extent and more accurate record changes in trace metal deposition (Watmough, Hutchison 1999). Zn, $\mathrm{Cu}$ and $\mathrm{Cr}$ are known to relate with the amount of air pollutants deposited on the stand (Pärn 2001).

\section{Statistical comparison}

Nonparametric Kruskal-Wallis $H$-tests were performed on each of the elemental parameters using the three treesampling techniques (Fig. 7). All the calculated $H$-values fail to exceed the critical $H$-value (at $\mathrm{p}<0.05$ ), indicating that there are no statistically significant differences between the elemental data of different tree-sampling techniques (Table).

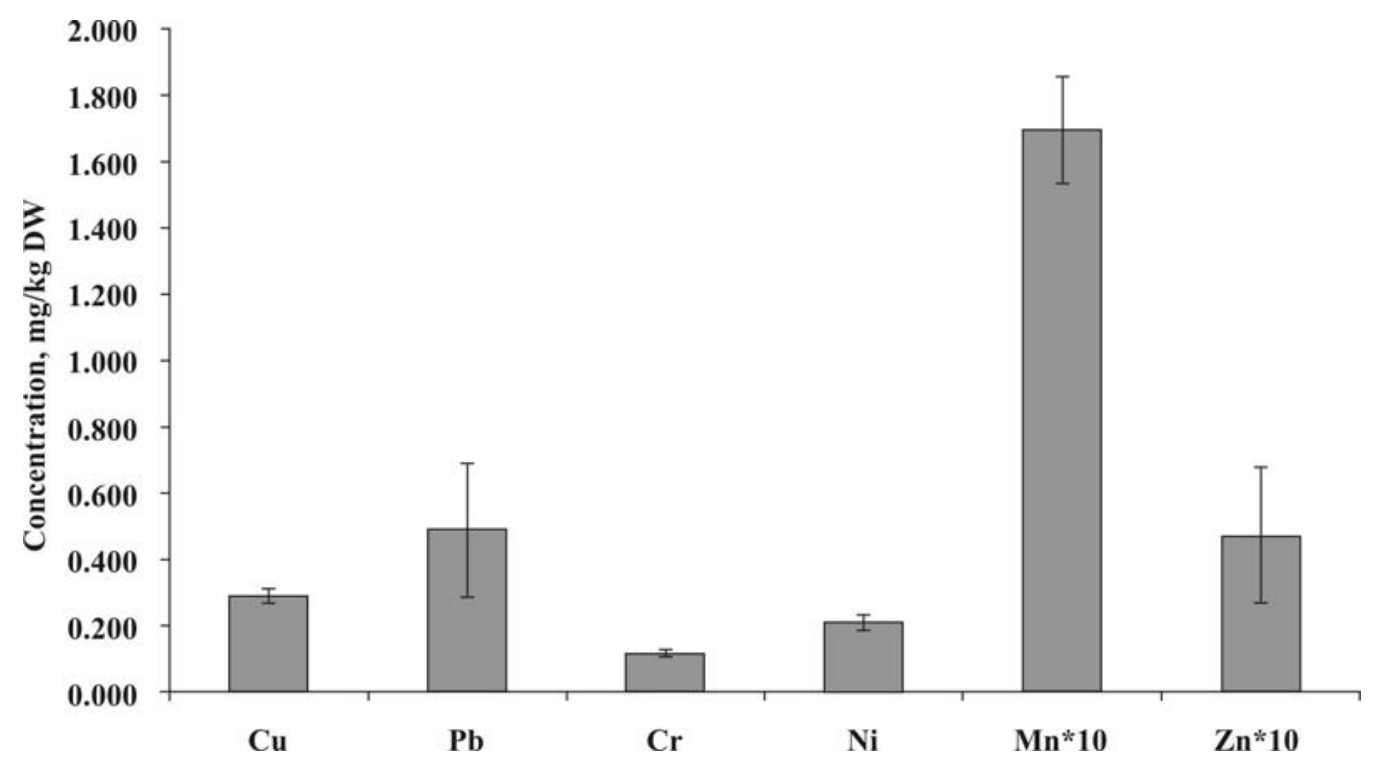

Fig. 6. Median data of metal concentrations in wood $(\mathrm{mg} / \mathrm{kg}$ dry weight) $(\mathrm{n}=24)$ 


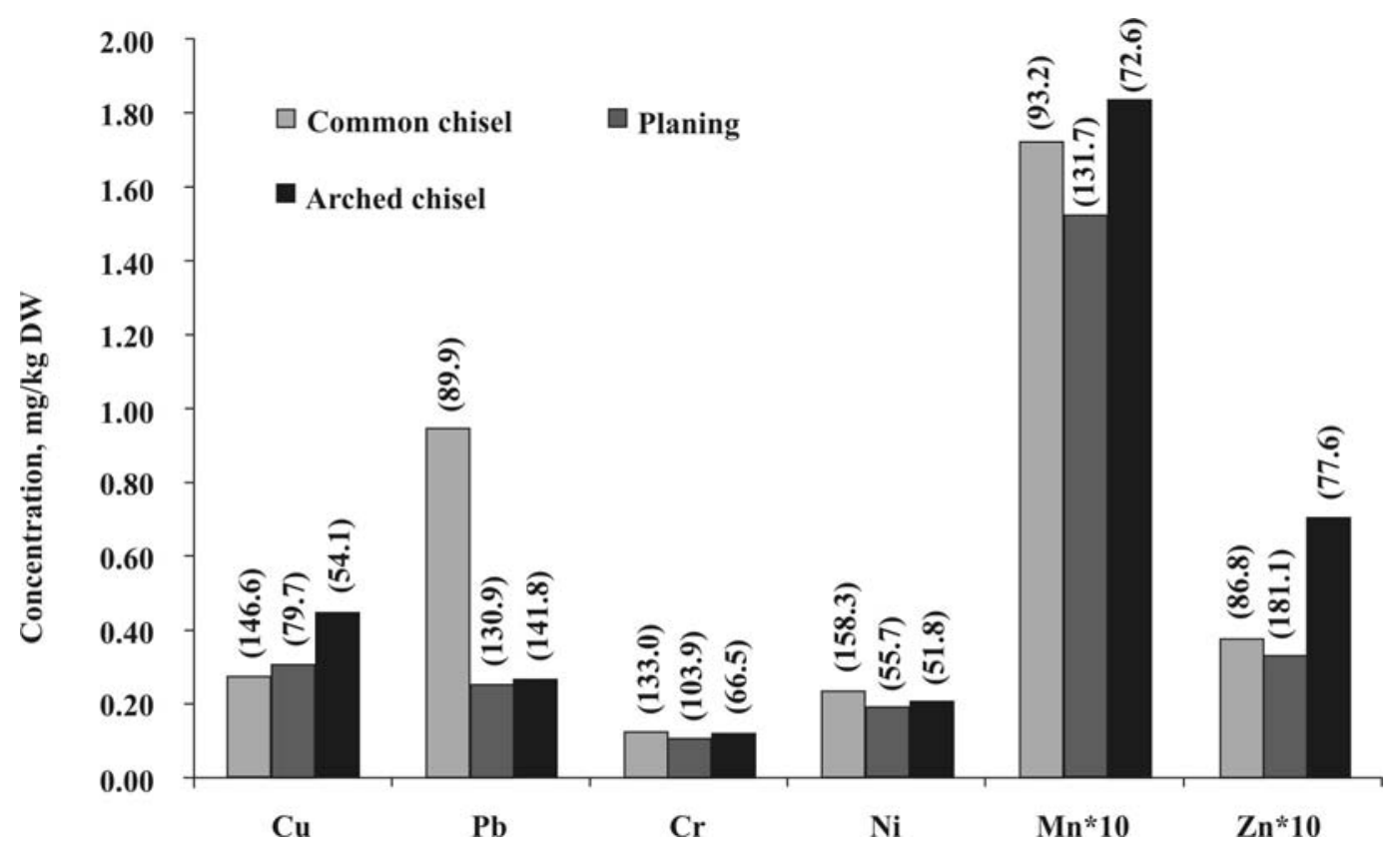

Fig 7. Median data of metal concentrations in wood ( $\mathrm{mg} / \mathrm{kg}$ dry weight) and the percentage coefficient of variation (in parenthesis) of the elemental data for each tree-sampling technique $(\mathrm{n}=8)$

Table. Kruskal-Wallis $H$-test analyses with p-values (in parenthesis) from the sample populations of the three sampling techniques for each elemental parameter $(\mathrm{n}=8)$

\begin{tabular}{c|c|c|c}
\hline $\mathrm{TM}$ & $\mathrm{H}$-value & $\mathrm{TM}$ & H-value \\
\hline $\mathrm{Cu}$ & $1.22(0.544)$ & $\mathrm{Ni}$ & $0.65(0.724)$ \\
\hline $\mathrm{Pb}$ & $2.90(0.235)$ & $\mathrm{Mn}$ & $1.37(0.505)$ \\
\hline $\mathrm{Cr}$ & $0.59(0.743)$ & $\mathrm{Zn}$ & $4.45(0.108)$ \\
\hline
\end{tabular}

Critical $H$-value $\mathrm{p}<0.05=9.49$

\section{Practical comparison of the techniques}

Practical comparison of the methods is further carried out according to the main four aspects: time consumed for sampling, method costs, skills required to conduct sampling and risk of errors. After comparison the overall evaluation is presented.

Time consumption for sampling is one of the most important factors. Rapid sampling methods always win over those that need time. Chisels and a plane can be used only for a felled tree. There are suggestions to use an increment borer to take a tree-ring sample, but the mass of a sample is rather small ( $\sim 0.1 \mathrm{~g})$ and for a sufficient amount (at least $5 \mathrm{~g}$ ) of a ring sample, sampling must be repeated.

Planing of tree rings takes approximately one hour, plus one further hour is needed to screw and split rings from the wood bore. Since statistically at least three rolls are taken from a tree-trunk, the sampling procedures will last for about 10 hours when using any of the tools. Therefore, in terms of time, all the three methods are comparatively similar.

Sampling costs are usually related with the costs of sampling equipment. Common chisels and a plane are the most typical instruments used in household, especially by furniture-makers. Arched chisels were specially created and patented (Pranas Baltrènas, Donatas Butkus, Riman- tas Beinaravičius LT 5358 B), therefore, it is is more difficult to acquire them.

Higher costs can be associated with a sufficient number of sampled trees. Each felling of a tree is a matter of permit and costs.

Complexity of tool application is of significant importance taking into account potential mistakes and influence on the quality of results. Tree felling and splitting into rolls require technical assistance. At least three people must be employed in sampling. A saw, one-man force and tree-cutting skills are required. Practice has shown that planing rather than chisel use is more skill-based. The chisel method requires more human force.

Invention of arched chisels was based to repeat concentric circles of tree-rings when splitting. This is extremely useful for rings having different curvatures in the southern and northern parts of a tree-trunk. This feature makes arched chisels superior to common ones because splitting a part of adjacent tree-ring wood is less probable. Furthermore, probability of a random error is then less possible.

The requirement for ring sampling is to take samples from different heights of the investigated tree $(1 \mathrm{~m}$ above the ground, in the middle of the tree-trunk and at 3/4 of the trunk height). This enables to compare TM concentrations at different trunk heights or homogenize wood of the same rings to determine mean TM concentrations along the trunk. In such a case only cutting down of a tree is possible and thus the use of all the above-mentioned methods then might be applied.

Further sample processing includes decomposition for which a mass of $0.1-0.5 \mathrm{~g}$ of wood sample is required. All the mentioned methods can be used according to wood sample mass. 


\section{Related future research areas}

This study has shown that various techniques can be successfully used to split the tree-rings of pine trees. However, the main disadvantage of all the mentioned methods is that a tree must be felled before further sampling. Bearing in mind that metal analysis requires a representative number of samples to produce reliable results, felling of a big number of trees may require time and labour. An increment borer, which becomes more popular for treering sampling also for metal analysis provides possibility of sampling a non-felled tree. In this case new risk, e.g. too small mass of sample, boring skills, must be considered.

\section{Conclusions}

1. Average values of metals in tree rings sampled with common chisels, arched chisels and a plane were $17.0 \pm 0.16 \mathrm{mg} / \mathrm{kg}$ for $\mathrm{Mn}, 4.70 \pm 0.21 \mathrm{mg} / \mathrm{kg}$ for $\mathrm{Zn}$, $0.49 \pm 0.20 \mathrm{mg} / \mathrm{kg}$ for $\mathrm{Pb}, 0.29 \pm 0.02 \mathrm{mg} / \mathrm{kg}$ for $\mathrm{Cu}$, $0.21 \pm 0.02 \mathrm{mg} / \mathrm{kg}$ for $\mathrm{Ni}$ and $0.12 \pm 0.01 \mathrm{mg} / \mathrm{kg}$ for $\mathrm{Cr}$ and were in the range of typical concentrations in the investigated region for Pinus sylvestris L. as well.

2. Statistical analysis (Anderson-Darlin test, KruskalWallis tests, median data and percentage coefficient of variation) revealed no significant differences between metal concentrations determined in tree rings which were sampled using common chisels, arched chisels and planing.

3. Various tools - common chisels, arched chisels and a plane - can be successfully used for tree-ring sampling, however, an increment borer provides possibility of sampling a non-felled tree.

\section{Acknowledgement}

The authors express their thanks to Dr Rimantas Beinaravičius for his assistance in wood sampling and allocating of equipment. He is a co-author of the Lithuanian patent Modified chisel (No LT 5358 B).

\section{References}

Alexander, D. E.; Fairbridge, R. W. 1999. Encyclopaedia of Environmental Science. USA: Springer. 365 p.

Antonova, G. F.; Cherkashin, V. P.; Stasova, V. V.; Varaksina, T. N. 1995. Daily dynamics in xylem cell radial growth of Scots pine (Pinus sylvestris L.), Trees 10: 24 30. doi:10.1007/BF00197776

Baes III, C. F. and McLaughlin, S. B. 1984. Trace Elements in Tree Rings: Evidence of Recent and Historical Air Pollution, Science 224: 494-497.

Baltrènaitè, E.; Butkus, D. 2004. Investigation of Heavy Metals Transport from the Soil to the Pine Tree, Water Science and Technology 50(3): 239-244.

Baltrènaite, E.; Butkus, D. 2006. Heavy Metals in Pinus Sylvestris L. Wood Infected with Heterobasidion annosum (Fr.) Bref, in Abstract book of COST 859 WG1 meeting in Santiago de Compostela, Spain, 22-24 June, 46.

Baltrènas, P.; Ignatavičius, G.; Idzelis, R.; Greičiūtė, K. 2005. Aplinkos apsauga kariniuose poligonuose. Vilnius: Technika. 302 p.
Beinaravičius, R. 2005. Dirvožemio ilgalaikès užtaršos radionuklidais kaitos tyrimas ir prognozé pagal ju kaupimasi medžiu segmentuose. Daktaro disertacija. Vilnius. 132 p.

Bindled, R.; Renberg, I.; Klaminder, J.; Emteryd, O. 2004. Tree rings as $\mathrm{Pb}$ pollution archives? A comparison of ${ }^{206} \mathrm{~Pb} /{ }^{207} \mathrm{~Pb}$ isotope ratios in pine and other environmental media, Science of the Total Environment 319: 173-183. doi:10.1016/S0048-9697(03)00397-8

Bowers, L. J.; Melhuish, J. H. 1987. Elemental analysis of red oak and loblolly pine growing near an inactive chromium smelter, in Presentation at the Sixth Central Hardwood Forest Conference, Knoxville, TN, February 24-26, 231-245.

Breckle, C. W. 1991. Growh under heavy metals, in Waisel, Y.; Eshel, A.; Kafkafi, U. (Eds.). Plant roots: the hidden half. New York, NY: Marcel Dekker, 351-373.

Butkus, D.; Baltrènaitè, E. 2007. Transport of heavy metals from soil to Pinus sylvestris L. and Betula pendula treles, Ekologija 53(1): 29-36.

Butkus, D.; Baltrènaitė, E.; Kaziukonienè, D. 2002. Estimation of Heavy Metals Accumulation in Tree rings, Environmental Engineering [Aplinkos inžinerija] 10(4): 156-160.

Butkus, D.; Beinaravičius, R. 2005. Distribution of ${ }^{137} \mathrm{Cs}$ and ${ }^{40} \mathrm{~K}$ in soils and tree rings of Lithuania, Geochemistry International 43(2): 197-201.

Butkus, D.; Matelis, A.; Pliopaite Bataitienè, I. 2007. Accumulation of radioisotopes associated with the presence of wood-inhabiting fungi in Scots pine (Pinus sylvestris L.) wood, Ekologija 53(3): 22-29.

Butkus, D.; Pliopaite Bataitienè, I.; Bataitis, T. 2008. ${ }^{90} \mathrm{Sr}$ kaupimosi paprastosios pušies (Pinus sylvestris L.) medienoje tyrimas, Journal of Environmental Engineering and Landscape Management 16(3): 121-127. doi:10.3846/1648-6897.2008.16.121-127

Camarero, J. J.; Guerrero-Campo, J.; Gutiérrez, E. 1998. Treering growth and structure of Pinus uncinata and Pinus sylvestris in the Central Spanish Pyrenees, Arct. Antarct. Alp. Res. 30: 1-10.

DeWalle, D. R.; Swistock, B. R.; Sharpe, W. E. 1995. Radial patterns of tree-ring chemical element concentration in two Appalachian hardwood stands, in $8^{\text {th }}$ Central Hardwood Forest Conference, University Park, PA. 4-6 March, 1990. General Tech. Rep. Ne-148. USDA For. Serv., North-eastern Exp. Stn., Radnor, PA, 459-473.

Godbold, D. L.; Hüttermann, A. 1985. Effect of zinc, cadmium and mercury on root elongation of Picea abies (Karst.) seedlings, and the significance of these metals to forest die-back, Environmental Pollution 38: 375-381. doi:10.1016/0143-1471(85)90108-4

Guyette, R. P.; Cutter, B. E.; Henderson, G. S. 1991. Longterm correlations between mining activity and levels of lead and cadmium in tree-rings of eastern red cedar, Journal of Environment Quality 20: 146-150. doi:10.2134/jeq1991.00472425002000010022x

Harju, L.; Lill, J. O.; Saarela, K. E.; Heselius, S. J.; Hemberg, F. J.; Lindroos, A. 1997. Analysis of of trace elements in trunk wood by thick-target PIXE using dry ashing for preconcentration, Fresenius Journal of Analytical Chemistry 385(4): 523-528. doi:10.1007/s002160050459

Hill, L. J. 2002. Branching out into biogeochemical surveys: a guide to vegetation sampling, in Roach, I. C. (Ed.). Regolith and Landscapes in Eastern Australia, CRC LEME, 50-53.

Horacek, P.; Slezingerova, J.; Gandelova, L. 1999. Effects of environment on the xylogenesis of Norway spruce (Picea abies [L.] Karst.), in Wimmer, R. \& Vetter, R. E. (Eds.). Tree-ring analysis, 33-53. 
Kadūnas, V.; Budavičius, R.; Gregorauskienė, V.; Katinas, V.; Kliaugienè, E.; Radzevičius, A.; Taraškevičius, R. 1999. Geochemical Atlas of Lithuania. Geological survey of Lithuania, Vilnius. 162 p.

Kardell, L.; Larsson, J. 1978. Lead and cadmium in oak (Quercus robur L.) tree rings, Ambio. 7: 117-121.

Katinas, V.; Kadūnas, V.; Radzevičius, A.; Zinkutė, R. 2002. Processes of chemical element dispersion and redistribution in the environment with wastewater sludge used for recultivation of woodcutting areas, Geologija 38: 3-11.

Kirchner, P.; Biondi, F.; Edwards, R.; McConnell, J. R. 2008. Variability of trace metal concentrations in Jeffrey pine (Pinus jeffreyi) tree rings from the Tahoe Basin, California, USA, Journal of Forest Research 13(6): 347-356. doi:10.1007/s10310-008-0093-5

Larsson, C.; Helmisaari, H. S. 1998. Accumulation of elements in the annual rings of scots pine trees in the vicinity of a copper-nickel smelter measured by scanning EDXRF, $X$-Ray Spectrometry 27: 133-139. doi:10.1002/(SICI)1097-4539(199803/04)27:2<133::AIDXRS254>3.0.CO;2-A

Latimer, S. S.; Devall, M. S.; Thomas, C.; Ellgaard, E. G.; Jumar, S. D.; Thien, L. B. 1996. Dendrochronology and heavy metal deposition in tree rings of bald cypress, Journal of Environment Quality 25: 1411-1499. doi:10.2134/jeq1996.00472425002500060035x

McLaughlin, S. B.; Shortle, W. C.; Smith, K. T. 2002. Dendroecological applications in air pollution and environmental chemistry: research needs, Dendrochronologia 20(12): 133-157. doi:10.1078/1125-7865-00013

Montse, T.; Joan, R. 2006. Leaching of heavy metals (Cu, Ni and $\mathrm{Zn}$ ) and organic matter after sewage sludge application to Mediterranean forest soils, Science of the Total Environment 363(1-3):11-22.

Nelson, L.; Conradie, S. D.; Turner, P. 2000. Progress in the use of near-infrared absorption spectroscopy as a tool for the rapid determination of pulp yield in plantation eucalypts, in Proceedings of IUFRO Conference "Forest Genetics for the next Millenium", Durban, South Africa, 8-13 October 2000, 1-13.

Nies, D. H. 1999. Microbial heavy-metal resistance, Applied Microbiology Biotechnology 51: 730-750. doi:10.1007/s002530051457

Nilsson, T. 2000. Innehåll av olika ämnen i årsringar från gran och tall - provtagna från olika plaster i Sverige [Content of various matters in yearly rings from spruce and pinesampled form various places in Sweden]. Uppsala, Swedish University of Agricultural Sciences, Department of Forest Soil. 55 p.

Ozolinčius, R. 2004. Lietuvos autochtoninès dendrofloros vertinimas pagal Elenbergo indikacinę skalę, Ekologija 4: $13-22$.

Ozolinčius, R.; Sujetovienė, G. 2002. Gamtinių ir antropogeninių veiksnių ittaka paprastosios pušies (Pinus Sylvestris L.) derèjimui Lietuvoje, Aplinkos tyrimai, inžinerija ir vadyba 4(22): 24-30.

Padilla, K. L; Anderson, K. 2002. Trace element concentration in tree-rings biomonitoring centuries of environ- mental change, Chemosphere 49: 575-585. doi:10.1016/S0045-6535(02)00402-2

Pärn, H. 2001. Variations of element concentrations in tree rings of Scots pine (Pinus sylvestris L.) in the vicinity of an oil shale-fired power plant, Oil shale 18(1): 57-71.

Poschenrieder, C.; Tolra, R.; Barcelo, J. 2006. Can metals defend plants against biotic stress? Trends in Plant Science 11(6): 288-295. doi:10.1016/j.tplants.2006.04.007

Rademacher, P. 2003. Atmospheric heavy metals and forest ecosystems. Institute of World Forestry. Hamburg. 34 p.

Rolfe, G. L. 1974. Lead detection in tree rings, Forest Science 20: 283-286.

Saarela, K. E.; Harju, L.; Rajander, J.; Lill, J. O.; Heselius, S. J.; Lindroos, A.; Mattsson, K. 2005. Elemental analyses of pine bark and wood in an environmental study, Science of the Total Environment 343: 231-241. doi:10.1016/j.scitotenv.2004.09.043

Schmitt, U.; Grünwald, C.; Gričar, J.; Koch, G.; Čufar, K. 2003. Wall structure of terminal latewood tracheids of healthy and declining silver fir trees in the Dinaric region, Slovenia, IAWA J. 24: 41-51.

Soon, Y. K.; Abboud, S. 1993. Cadmium, chromium, nickel, in Carter, M. R. (Ed.). Soil Sampling and Methods of Analysis. Boca Raton, FL: Lewis, 101-108.

Stravinskienè, V. 2005. Bioindikaciniai aplinkos vertinimo metodai. Kaunas: Vytauto Didžiojo universiteto leidykla. $215 \mathrm{p}$.

Stravinskienė, V.; Erlickytè-Marčiulionienė, R. 2009. Scots pine (Pinus sylvestris L.) radial growth dynamics in forest stands in the vicinity of "Akmenès cementas" plant, Journal of Environmental Engineering and Landscape Management 17(3): 140-147. doi:10.3846/1648-6897.2009.17.140-147

Stravinskienè, V.; Šimatonytė, A. 2008. Dendrochronological research of Scots pine (Pinus sylvestris L.) growing in Vilnius and Kaunas forest parks, Journal of Environmental Engineering and Landscape Management 16(2): 5764. doi:10.3846/1648-6897.2008.16.57-64

Taylor, A. M.; Gartner, B. L.; Morrell, J. J. 2003. Co-incident variations in growth rate and heartwood extractive concentration in Douglas-fir, Forest Ecology and Management 186: 257-260. doi:10.1016/S0378-1127(03)00278-0

Trapp, S.; Larsen, M.; Legind, C. N. 2007. A guide to vegetation sampling for screening of subsurface pollution. Biotool project, Denmark.

Watmough, S. A.; Hutchison, T. C. 1999. Change in the dendrochemistry of sacred fir close to Mexico City over the past 100 years, Environ. Pollut. 104: 79-88. doi:10.1016/S0269-7491(98)00150-X

Wells, C. G.; Jorgensen, J. R.; Burnette, C. E. 1975. Biomass and mineral elements in a thinned loblolly pine plantation at age 16. U.S. For. Serv. Res. Pap. SE-126.

White, R.; Tard, L. A. 2002. Investigating Environmental Pollution through Dendrochemical Analysis, OSCAR Journal 9. Available from Internet: <www2.selu.edu/ $>$.

Wilson, M. V. 2005. Simple random sampling in the field. Oregon State University, USA. 


\section{MEDIENOS RIEVIŲ ĖMINIŲ ĖMIMO SUNKIŲJŲ METALŲ ANALIZEI METODŲ PALYGINIMAS}

\section{E. Baltrènaitė, D. Butkus, C. A. Booth}

Santrauka

Medienos metinių rievių analizė suteikia informacijos apie medžio vystymąsi, svarbios inventorizuojant miškus, vertinant aplinkos poveiki, atliekant aplinkos oro ir dirvožemio monitoringą. Sunkiujų metalų koncentracijos metinėse rievèse susijusios su metalų koncentracijomis aplinkoje ir gali nusakyti vietinės aplinkos taršos lygi. Vienas iš svarbių medienos analizės etapų yra metinių rievių ėminių ėmimas. Siekiant tiksliai nustatyti sunkiujų metalų koncentraciją metinejje rievejje svarbu išvengti atsitiktinių paklaidų. Šiame darbe aptariami trys metinių rievių ėminių ėmimo metodai (iprastiniai kaltai, lenktieji kaltai ir obliavimas) ir lyginamos pagrindinių sunkiujjų metalų ( $\mathrm{Mn}, \mathrm{Zn}, \mathrm{Ni}, \mathrm{Cu}, \mathrm{Cr}, \mathrm{Pb})$ koncentracijos ėminiuose, paimtuose kiekvienu iš minètujų metodų. Vidutinės sunkiujų metalu koncentracijos, nustatytos šiais metodais, siekė $17,0 \pm 0,16 \mathrm{mg} / \mathrm{kg} \mathrm{Mn}, 4,7 \pm 0,21 \mathrm{mg} / \mathrm{kg} \mathrm{Zn,} \mathrm{0,49 \pm 0,20} \mathrm{mg/kg} \mathrm{Pb,}$ $0,29 \pm 0,02 \mathrm{mg} / \mathrm{kg} \mathrm{Cu}, 0,21 \pm 0,02 \mathrm{mg} / \mathrm{kg} \mathrm{Ni}$ ir $0,12 \pm 0,01 \mathrm{mg} / \mathrm{kg} \mathrm{Cr}$ ir buvo panašios i koncentracijas, aptiktas Pinus sylvestris L. medienoje nagrinėjamoje teritorijoje. Apskaičiuotos vidutinès vertès. Atlikus statistinę analizę (Anderson ir Darlin testas, Kruskal ir Wallis testas, variacijos koeficientas) tebuvo tik nereikšmingas sunkiujų metalų koncentracijų metinėse rievėse skirtumas, ėminius èmus aptartais metodais. Ivairūs metodai - ịprastiniai kaltai, lenktieji kaltai ir obliavimas - gali būti sèkmingai taikomi metinių rievių èminiams imti, tačiau „amžiaus“ grąžtu èminius galima imti nenukertant medžio.

Reikšminiai žodžiai: „amžiaus“ grąžtas, kaltas, medienos ėminiai, metinè rievè, obliavimas, sunkieji metalai.

\section{СРАВНЕНИЕ МЕТОДОВ ВЗЯТИЯ ПРОБ ГОДИЧНЫХ КОЛЕЦ ДРЕВЕСИНЫ ДЛЯ АНАЛИЗА ТЯЖЕЛЫХ МЕТАЛЛОВ}

\section{Э. Балтренайте, Д. Буткус, К. А. Бут}

Резюме

Анализ годичных колец древесины предоставляет информацию о развитии дерева, что важно для инвентаризации леса, оценки воздействия на окружающую среду и мониторинга воздуха и почвы. Концентрации тяжелых металлов в годичных кольцах древесины зависят от их концентрации в окружающей среде и могут свидетельствовать об уровне загрязнения местности. Одним из важных этапов анализа древесины является взятие проб годичных колец. Для точного определения концентрации тяжелых металлов в годичных кольцах древесины важно избежать случайных погрешностей. В статье анализируются три метода взятия проб годичных колец древесины (дробление обычным долотом, круглым долотом и строгание) и сравниваются концентрации основных тяжелых металлов ( $\mathrm{Mn}, \mathrm{Zn}, \mathrm{Ni}, \mathrm{Cu}, \mathrm{Cr}, \mathrm{Pb})$ в пробах, взятых каждым из названных методов. Средние концентрации тяжелых металлов при их измерении указанными методами достигали 1,695 $\pm 0,161$ мг/кг для $\mathrm{Mn}, 0,471 \pm 0,206$ мг/кг для $\mathrm{Zn}, 0,487 \pm 0,202$ мг/кг для $\mathrm{Pb}, 0,290 \pm 0,021$ мг/кг для $\mathrm{Cu}, 0,210 \pm 0,023$ мг/кг для $\mathrm{Ni}$ и 0,117 $\pm 0,010$ мг/кг для Cr. Эти концентрации тяжелых металлов аналогичны концентрациям в древесине сосны (Pinus sylvestris L) на данной исследуемой территории. При помощи статистического анализа [тест Андерсона-Дарлина (Anderson-Darlin), тест Крускаля-Валиса (Kruskal-Wallis), коэффициент вариации] выявлена лишь незначительная разница между концентрациями тяжелых металлов в годичных кольцах древесины, взятых уже названными методами. Методы дробления обычным долотом, круглым долотом и строгания могут успешно применяться для взятия проб годичных колец древесины, однако сверло „века“ предоставляет возможность взятия пробы без спиливания дерева.

Ключевые слова: сверло „века“, долото, пробы древесины, годичные кольца, строгание, тяжелые металлы.

Edita BALTRÉNAITÉ. Dr, Associate Professor at the Department of Environmental Protection, Vilnius Gediminas Technical University. She gained her Environmental Engineering and Landscape Management Ph.D in 2007 from Vilnius Gediminas Technical University (Lithuania). Publications: author/co-author of $\sim 25$ scientific papers. Research interests: metal uptake and translocation in higher plants, anthropogenic impact, soil contamination, and environmental management.

Donatas BUTKUS. Dr Habil of Science in Environmental Engineering at Vilnius Gediminas Technical University, 1999. Membership of the International Academy of Ecological and Life Protection Sciences. Publications: author of more than 200 research papers, co-author of monograph Geophysical problems of atmospheric krypton-85 (in Russian and English). Research interests: accumulation of radioactive noble gases, their interaction with environmental bodies, self-cleaning of atmosphere, influence of ionizing radiation of radioactive noble gases on geophysical processes; environmental physical pollution and the consequences of the Chernobyl nuclear accident on Lithuania.

Colin A. BOоTH. Dr, Senior Lecturer in Environmental Engineering at the School of Engineering and the Built Environment, The University of Wolverhampton. He gained his Environmental Science Ph.D. in 2002 from The University of Wolverhampton (UK). Publications: author/co-author of $\sim 50$ scientific papers and chapters. Research interests: environmental magnetism, soil erosion and conservation, soil management, water engineering and management, urban pollution, coastal and estuarine science. 